\title{
Balinese Folktales As A Medium: Modifying Stories Of The Special Need Concept To An Early Age Children
}

\author{
Luh Ayu Tirtayani ${ }^{1}$, I.G.A.A. Wulandari ${ }^{2}$, Lucky Ade Sessiani ${ }^{3}$ \\ 1,2Jurusan Pendidikan Dasar, Universitas Pendidikan Ganesha, Singaraja \\ ${ }^{3}$ Jurusan Psikologi, Universitas Islam Negeri Walisongo, Semarang \\ e-mail: 1ayu.tirtayani@undiksha.ac.id, ${ }^{2}$ ayu.wulandari@undiksha.ac.id, ${ }^{3}$ lucky_sessiani@walisongo.ac.id
}

\begin{abstract}
This article aimed at exploring more deeply the efforts made by teachers of early childhood education in introducing concepts of children with special needs. This article investigated the teachers' creativity in introducing concepts containing local values to children with special needs, which can support inclusive education. This study used an exploratory research model, with the aim of obtaining explanations of the relationships of causality case. The study was conducted to the teachers on early childhood education in Denpasar Bali. The subjects were determined by verifying the early childhood education institutions which had children with special needs first and this ended up with the involvement of 13 teachers from 10 early childhood education institutions in Denpasar. The data were collected through observation, directed individual and group interviews. The data were analyzed qualitatively by modifying Miles and Huberman's interactive model. The result showed that the teachers have introduced some types and characteristics of children with special needs by using tales as media and have creatively modified Balinese folktales to fit the needs.
\end{abstract}

Keywords: storytelling, empathy, children with special needs, early childhood education, inclusive education

\section{Introduction}

This study was an exploratory investigation into the efforts made by teachers of early childhood education in introducing the concepts of children with special needs to the students. There are a substantial number of children with special needs in Indonesia, and they have varied characteristics. As an illustration, the data from the Central Bureau of Statistics (BPS) in 2007 showed that there was $10 \%$ or 8.3 million children in Indonesia (the total population of children was $82,840,000$ ) were categorized as children with special needs or disabled (Mujaddid, 2014). The data is in line with the WHO estimate, in which children with special needs constitute of $7-10 \%$ of the population. The result of the National Social Economic Survey (Susenas) in 2012 (Diono, 2014) showed that the Indonesians with special needs reached the number of 6.515 .500 (2.45\% of the population). The characteristics of the special needs are varied, as presented in the Data Collection on Social Protection Program (PPLS) in 2011, that is, children with physical and mental disabilities $(19,438)$, disabled $(32,990)$, blindness $(5,921)$, deaf and hard hearing $(3,861)$, speech/language disorder $(16,335)$, hard hearing with speech impairment $(7,632)$, blind and hard hearing combine with speech/language disorder $(1,207)$, disabled combine with hard hearing and speech disorder $(4,242)$, children with hard hearing, speech defect, blind and disabled (2.991), mental retardation $(30,460)$, dan children with mental disorder $(2,257)$. The Ministry of Education and Culture in 2018 announced that the number of children with disabilities in the academic year 2017/2018, in which Bali Province occupied the big ten position (Lokadata, 2017). In the academic year of 2017/2018, there were 3400 students in Bali Province who were categorized as students with special needs. Of course, the data does not nationally reflect the whole number of children with special needs, because some families still tend to hide the condition of their children, for many various reasons.

As an Indonesian child, students with special needs also have an equal right with those of the normal ones, including the right to have an appropriate education. Education for children with special needs has been focused on special schools called SLB. SLBs are available from the level of kindergarten (called TKLB) to the senior high school level (called 
SMALB). But, these schools are a few in amount. The data of the Ministry of Education and Culture (2016) showed that the number of special schools (public and private) that were found in Bali Province was only 16 SLBs. This number can be called to be a few if compared to the number of students who were categorized as students with special needs (3400 students). Not only a few in number, but these special schools are also generally located in a city center or regency capital. So, that is not yet able to answer the fact because the students with special needs are spread to almost all regions in Bali, not only in cities. Consequently, some of these children do not have access to a good education. Thus, the government is trying to provide an education with a special strategy that is adapted to the special characteristics of children, that is, the existence of difficulty in joining a lesson. Therefore, the government is trying to provide an education with a special strategy that is adapted to the special characteristics of children, that is, the existence of difficulty in joining a lesson (Kementerian Pendidikan dan Kebudayaan, 2003). For children at early ages, they designed an early education program which is called PAUD Inklusi (Inclusive for early childhood education).

As an Indonesian child, students with special needs also have an equal right with those of the normal ones, including the right to have an appropriate education. Education for children with special needs has been focused on special schools called SLB. SLBs are available from the level of kindergarten (called TKLB) to the senior high school level (called SMALB). But, these schools are a few in amount. The data of the Ministry of Education and Culture (2016) showed that the number of special schools (public and private) that were found in Bali Province was only 16 SLBs. This number can be called to be a few if compared to the number of students who were categorized as students with special needs (3400 students). Not only a few in number, but these special schools are also generally located in a city center or regency capital. So, that is not yet able to answer the fact because the students with special needs are spread to almost all regions in Bali, not only in cities. Consequently, some of these children do not have access to a good education. Thus, the government is trying to provide an education with a special strategy that is adapted to the special characteristics of children, that is, the existence of difficulty in joining a lesson. Therefore, the government is trying to provide an education with a special strategy that is adapted to the special characteristics of children, that is, the existence of difficulty in joining a lesson (Kementerian Pendidikan dan Kebudayaan, 2003). For children at early ages, they designed an early education program which is called PAUD Inklusi (Inclusive for early childhood education).

The basic concept of the inclusive education is intended as a service system of education which includes children with special needs to learn in a regular class together with their peers, located close to the place where they live (Rachmawati, Nu'man, Widiasmara, \& Wibisono, 2016). PAUD Inklusive is inspired by the enthusiasm to provide opportunities for all children to get a quality education that is in accordance with their needs, without any discrimination (Mastuti, 2014). The instruction is specially designed in order to ensure that the lesson can be learned by the students optimally (Hallahan, Kauffman, and Pullen, 2015), including instructional material and techniques, curriculum, evaluation system, and supporting facilities which are adequate to the learning process.

PAUD Inklusi places normal children and children with special needs at the same setting and the education is conducted together to optimize the children's potency (Hopman et al., 2018; Ruijs, 2017). However, it cannot be denied that prejudice and discrimination against children with special needs are common in society. Prejudice and discriminative behavior arise from a negative judgment which regards individuals with special needs as imperfect children who are vulnerable so they do not have an equal opportunity in education (Carlie, 2013). Such prejudice and discrimination can originate from a misconception to the noble values in a particular community. At the same time, this misconception reinforced by the existing institutions, which then made fewer opportunities for children with special needs to study in a good educational setting. For example, parents with discriminative behavior to special needs people tend to adopted by their children. Children are oriented to their parent's behavior to look to others with special needs. They have learned the negative behavior of 
their parents. Further, children will behave discriminatively towards other children with special needs in the school.

Negative views of parents become a barrier for children to better known of children with special needs. A limitation created by parents and other social environments can hinder the social skill development of children in cooperating with others. A restriction of children in obtaining opportunities makes them unable to develop their social skills to cooperate with other children well. Social skill belongs to the skill to do activities (interacting and cooperating) together with peers who have a special need. That poor of social skill obviously in contradictory to inclusive education, which required a student' acceptance to their peer who has special needs.

To minimize the negative effect from the lack of student acceptance to others with a special need, the teachers of the early childhood education need to participate in introducing the concept of children with special needs and appropriate social attitudes in the school setting. This is important to be done at the early childhood education level since as we know an early age is a golden age for stimulating children's ability comprehensively, especially in their psychosocial aspects (Darling-Churchill \& Lippman, 2016; Jones, Zaslow, DarlingChurchill, \& Halle, 2016). At an early age, children learn to know the existing social environments around them. Parallel to the effort knowing their social environment, children at an early age also learn to give responses accurately to various social phenomenon. Children at an early age have the opportunity to learn and next to be able to give social responses by considering values or expectations that prevail in their community.

An effort to stimulate social responses that are appropriate for peers with special needs, both in the classroom setting and other broader environments, does need to be conducted at an early age (Kocaj, Kuhl, Jansen, Pant, \& Stanat, 2018; Rutherford, 2016). The sufficiency of social competence is needed by the student in line with the increasing opportunities for children with special needs to be able to learn together with their peers through an inclusive education program. The inclusive program which is increasingly promoted by the government, even at a regional level, becomes the gate to fulfill the rights of the children with special needs in getting a good education. This special program also becomes a condition which gradually necessitates students to get an understanding about the concept of special needs, and the social skill which is sufficient in the communicating and interacting process with the peers who have a special need in the classroom.

The understanding of the concept of children with special needs and positive attitude toward special needs will lead the children at an early age to behave appropriately toward their peers in the classroom who have special needs. The good social skill ability and attitudes will bring up a more appropriate social behavior toward adults who also have special needs. Through a learning activity of introducing the concept of children with special needs and habituation of an appropriate social attitudes and also the managed of setting of learning activities together in an inclusive classroom then it is expected that the anti-bullying character toward children with special needs (empathic, responsive and responsible) can be developed at an early age.

In an effort to develop the anti-bullying character towards special need children in early age students, we must consider to the values of the local community themselves (in this case the Balinese people) regarding the special needs people. Local values are the seeds of character, which basically already exists in an individual, as part of his community. Character is attached to local values, as a noble human potential. Characters will color behavior and then it is judged by others according to the social parameters that apply in society. The scarcity of learning media about children with special needs, especially in local values-based education media is a challenge for early childhood teachers.

The effort to induce the local values in early age education corresponds to the contextual learning approach, which is a reference in early childhood education in Indonesia. In line with the orientation to develop an anti-bullying attitude toward children with special needs at an early age, then needed to explore deeply the efforts made by teachers, in this case, are teachers of early childhood education in Denpasar, Bali on introducing the local value about special needs people to their students. The use of appropriate teaching methods 
and media will create a good learning atmosphere, especially making the learning process more conducive in inclusive early childhood education classes. Appropriate social behavior which stimulated properly since an early age will support the children later in their communities.

\section{Methods}

This study used the qualitative approach with the exploratory type (the old term was explorative). The focus in this study was on the efforts on the part of the teachers to introduce the types and characteristics of children with special needs, and the attitudes that are tolerant toward the children with special needs. This exploratory study made it easier for the researcher to explain the efforts made by the teachers to prepare media for introducing the concept of special needs to the students. With this method, the researcher could explore more deeply topics that are related to the concept of special needs outside the general understanding that has so far developed in society. In this context, the use of the local folktales as the medium in learning contained rich local values about the individuals with special needs and attitudes that appropriate toward the phenomenon, became the object of the study. The topic developed in this study was the concept of children with special needs, a term which has undergone a change into something more civilized, that is, from the concept of children with defects or physically/ mentally weak children. The researchers presumed that the concept of children with special needs is not new (in Bali) which has started to be heard by the public but has not yet been clearly used in the context of early childhood education. Hence, this study was designed with high flexibility that enabled the researchers to become creative in designing the steps of the study. This creativity encouraged an unstructured and nonstandard research procedure, as what is often found in descriptive research (Guba \& Lincoln, 1994), thus, it has the consequence on the method of data collection.

In this study, the technique of observation, interview, and focus group discussion (FGD) was employed in an integrated way (Kreuger, 1988; Morgan, 1988). The subjects were determined by using the parameter of the relationship between school and inclusive education activities, that is, the presence of children with special needs and the use of local wisdom, in this case, is Balinese folktales, in the teaching and learning process. The result showed that there were 10 early childhood education institutions which include the category. The focus of observation was the process of telling a story (preparation and implementation) by the teachers (13 teachers as the subjects) to their students. Data includes the use of stories in introducing concepts of special needs, efforts to modify local stories, perspectives and social attitudes towards children with special needs that needed to stimulate from an early age, and efforts made by teachers to introduce the concept of special needs. To get a deeper understanding, an interview was done with every subject to find out the process of selecting stories, the efforts to understand the concepts of certain special needs, an evaluation of the story in terms of its suitability with the topic of the special needs, the modification of folktales, and the process of transmitting local values in the stories to children of an early age. Focus group discussion (FGD) was done twice, the first group FGD consisted of 6 teachers of early childhood education, and the second FGD involved 7 teachers of early childhood education. The main intention of this FGD was to listen to inputs, experiences, and expectations of the subjects in the use of the media to introduce the concept of children with special needs which contains local values. The data in the form of texts were then processed through the coding technique and the determination of themes related to the data. Data coding help in developing insights to understand text and subtext categorizations that surfaced in the study, especially the narration of the concept of special needs, local values, and social attitude toward people with special needs which are developed in the early ages. 


\section{Results and Discussion}

The findings of the effort to modify Balinese folktales in the process of introducing the concept of special needs for the early age students were divided into two subdivisions as follows.

a. Introducing the types and characteristics of special needs through the medium of tales.

A child with a special need is not a new concept. Previously the term used was 'child with defect'. The concept of 'defect' is based more on the medical paradigm, that is, to see an imperfection of a child compared to other children. This weakness is dominant, especially in the child's psychological aspect. Although not as an entirely new concept, the concept of special needs should first be introduced to children at an early age. According to the research findings, the teachers of early childhood education face a rise in the number of children with special needs who join to learn in the classroom. The increase is significant if compared to the previous decade. In some institutions, children with special needs enroll every year to the new class. This obviously has an effect on the rise of the need for regular student knowledge about others with special need and also the skills to be able to behave positively toward their special needs' peer groups.

The open of the opportunity for children with special needs to join the lesson in the regular early childhood education requires a new skill of the teacher, that is a competency to be able to involve all the students in the learning process on their classroom. It means that the teacher must have a strategy to manage the classroom setting and also to teach the regular student so they are able to accept the peer groups with special needs. The students' acceptance of their special needs' friends in the classroom daily activities is the beginning of the student involvement stage in the lesson.

Peer acceptance has a positive impact, strengthens self-respect of children with special needs toward their conditions and abilities. The belief that they are worthy of respect also impact the children' self-confidence to participate in their classrooms learning activities. This positive self-confidence makes them willing to engage in classroom activities and also with their friends. Not just in a classroom setting, positive self-confidence also makes them willing to cooperate in other settings, such as on-stage performances ('panggung gembira', exhibition, and Carnaval). Based on the illustration, it becomes increasingly important to develop the children understanding about their special needs peer's, then to make them as a friend who can accept and be socially responsible for their special need peer.

In an effort to develop the children understanding about their special needs peer's, the teachers of early childhood education in Denpasar are chosen to educate their student by using a storytelling method. The teacher uses the active storytelling method, by including movement and songs during the storytelling activities. Through the stories, teachers could describe the condition of children with special needs includes their various characteristics. By telling a story and adapt the content and method of presentation of the story, a teacher could present the social values (especially Balinese values), so it can be able to be understood by children of an early age. By listening to the stories, do active moves, and interacting through the stories, the student got a point of the concept, experiences and learned utterances, and also retained it in their early age memories.

Since the student is at the early age children who had not yet been able to understand an abstract concept comprehensively, the teacher complimented the learning process with a visual learning media. The visual media had the theme of children with special needs. This method was effective because the student showed their interest to come and joint with the activities. These interesting activities become a joyful and meaningful learning experience to the student. Those meaningful activities would make a student easier to understand the learning point about special need children, that was inserted into the stories. A joyful and meaningful experience produces a positive impression of the learning process for the children. 


\section{b. An Effort to Modify Balinese Folktales (Satua Bali) by Inserting the Concept of Special Need Children}

Based on the result, the introduction of the concept of special needs to the children of an early age has been done by the teachers through the use of a modified folktale. The stories selected were Balinese folktales, or also known as satua Bali. The selection was based on two important considerations. First, these Balinese folktales (satua) are contextual for the children. These stories contain local values of the community where the children live. Secondly, they have been considerably known and understood by the teachers of early childhood education themselves. The teachers had got previous experiences about the contents that they would teach to the children. In the process of introducing the concept to the children with special needs, the teachers judged that the use of Balinese folktales (satua) had met the contextual element since the stories originated from the cultural values or local wisdom that are present in Balinese community. Balinese folktales contain local elements of Balinese life. In addition to the reason that the material is contextual, the folktales have been known and understood by adults around the children. This understanding will be useful to the children of an early age, that is, they can relate the concept they get in the classroom to the opinions of the significant others in their community.

Most of the stories used by the teachers have been printed as a books (written references), which included 'I Belog' (Supatra, 2016), 'Nang Bangsing teken I Belog' (Tinggen, 1994), 'I Sigir dan Dewa Matahari' and 'I Lara dan Sapi Putih' (Taro, 2014). Other stories were having been transmitted orally from generation to generation, such as: 'I Buta lan I Bongol', 'I Buta lan I Rumpuh', 'I Siap Doglagan', 'I Kolok', and 'I Siap Selem'. They present figures that have special needs, such as blind, hard hearing, speech impaired or paralyzed. Other stories do not explain the types of special needs as explained before, but give explanations about the imperfect physical characteristics, such as the form of the body which does not look like that of a normal child (long neck, short legs, walking in a stooping position, etc.), and a cognitive ability which is prone to be low (as the characteristics of a mental retardation).

The process of writing the stories was done by the teachers gradually. The first step was to determine the purpose or target of the story to be told to the children. The purpose or target is the basis for arranging materials and preparing sources or media. In the process of introducing the concept of children with special needs, the teachers had decided to use Balinese folktales. Based on experiences, the Balinese folktales contain basic materials needed by children of an early age. However, the number is very limited. Only a few Balinese stories contain the concept of special needs. If any, the stories tend to contain the same special need. For example, sight impairment, paralysis ('I Perot') and hard hearing ('I Bongol'). Consequently, the teachers had difficulty when introducing the other forms of special needs, that refer to the categories of special needs children that is possible to join in early childhood education. Another problem is the common tendency that to see the handicapped people as an insane individual, which when related to the general concept of special needs this perspective is not acceptable. Therefore, the teachers attempted to find local terms which are capable of describing the existing categories of children with special needs.

To meet the learning requirement, teachers modified the stories of selected folktales and added important elements that are related to the characteristics of special need. To meet the learning requirement, teachers modified the stories of selected folktales and added important elements that are related to the characteristics of special need. That stories will be used in the classroom learning activity. Modification to the existing stories was done by elaborating the contents and the method of storytelling. The content elaboration was done by adding materials which had not been covered and inserting clearer pictures about the characteristics of children with special needs. The materials about the concept of special needs were obtained by the teachers from the literature (by reading books or online articles), the professional explanation through seminars and training, information from medical doctors and psychologists, and additional elements from the experiences of the parents who had children with special needs. The descriptions were made simple but remained adequate for 
the process of learning. The materials about the characteristics of each type of special needs category were made simple and intended to make the student can recognize and understand it. The addition about characteristics of children with special needs obtained from the parents can make other children easy to understand about their special peer. Not only about the behavior of special need children and appropriate response in the classroom, but also at the setting of their community. For example, a teacher used Balinese folktale entitled "I Belong" by also inserting materials related to other characteristics of special needs as an addition to the children's knowledge. I Belog is a story about a child who has a low cognitive ability. In this case, the teacher modified the story and gave the point to their humble, easy going, and the treatment as what should be given by normal children when they meet individuals like I Belog. This story gave a description as an example of fact to the children's thoughts, which then can be used when children meet someone with those characteristics. Another modification was made by adding hyperactive characteristics. Thus, children are expected to be able to differentiate cognitive barriers and behavior barriers such as hyperactivity.

At the next step, the teacher prepared the learning media such as pictures, photos, or puppets of the characters in the story. Those media are the most favorite since they are effective in forming the children's understanding of the concept of special need. According to Nur'aini (2010) children think in pictures. In other words, the language of children's thought is visual language. All information received will be stated in their thought in concrete forms. This form of thought, of course, a line to the children's ability of understanding. Hence, the description of the concept that was given to the early age children must suitable for their age. To be more effective, the pictures should be placed in a meaningful context and need to give the opportunity to the children to interact with it. That just to make sure that an appropriate information process will take place in those children's set of thinking. The understanding of a concept that is well organized will have a positive impact on retention. Another reason for selecting visual media or puppets in the early childhood learning process is because these media are easy enough to make and are relatively cheap.

The modification in the contents of the story seen in the lesson plans (RPPH). RPPH is the reference to all teaching and learning activities done by the teacher. RPPH stated the materials targeted, method, and also teaching-learning media used in the process of learning. The selection of a suitable story and elaboration of the contents of the story, implementation, and evaluation of the learning achievement expected can be known from the classroom's RPPH. According to the 2013 Curriculum, at Core Competence 2 (KI2) about social attitude, that so it is important to plan habituation of good behavior towards others. In this objective, the storytelling method is very suitable. Telling stories method to the early age children needs to be done repeatedly, but still, the principle of joyful learning cannot be ignored. As a challenge, telling stories method in the early age classroom must be done repeatedly. Repeating story could make a chance of a better understanding, especially to the early age children. Therefore, the simplification and elaboration of the story are very important in order that materials taught are comprehensive but simple, and remain as a new experience for children at every meeting. A teacher just has to make a modification, in the way to tell the story, variation of the media, or the active movement through the story. Modification could make the story as a new experience in every time it faced by the student, even though it was a repeating story. Storytelling method in learning process made possible experiences to develop a better understanding of the values and concept of special need people that are included in the stories.

In light of the discussion about the findings, it is apparent that the concept of special need is not new in the field of education, especially in early childhood education. This concept has been around for a long time, but the term 'child with impairment' has a negative consequence. The change of the concept into a more positive one is based on the improvement in the understanding of the teachers, families, and the community members about the cause and characteristics of children with special needs. The better understanding and paradigm in introducing and teaching the special need student is also felt and experienced by the teachers of early childhood education. 
Theoretically, the detection of some types of special needs in children can be made from an early age (Haryanto, 2010; Tim Dirjen Pembinaan Kesmas, 1997). In line with the improvement of parents' awareness of their special needs children's, the children have also got more opportunity to get a professional treatment, both clinically and educationally. The improvement of the parent's knowledge will also have an impact on the increase of special needs student that join the formal education. That situation pushes an effort made by the teachers to introduce children with special needs to other students in their classroom. Thus, an effective effort in stimulating children's social ability in accepting and involving their friends with special needs especially in learning activities in the classroom will be increasingly needed.

The parent's acceptance helps them to have an experience with their special children. Parents' acceptance of the condition of their children becomes a good learning material to the teacher in the effort to understand the special need student in the school (Basith \& Hengky, 2017). The description of parents' experiences becomes useful materials for the story because it can enrich the contents and also give a new nuance about children with special needs. The experiences of parents are transmitted to the children through the active role of the teachers. This is a kind of collaborations which appreciate local values very much from the daily experiences of the families. This contextual teaching approach is very suitable at the level of early childhood education.

The movement that fought for equality in education services was increasingly intense (Kustawan dan Budi, 2013). This is in line with the increase in the number of children with special needs who have been detected by the government and can be taught in the school setting (Mujaddid, 2014). The detection of children with special needs showed an increase in the number which impacts the requirement of education for all. One of the policies is the provision of education for early children with special need in regular classes which is known as inclusive early childhood education (Kustawan \& Yani, 2013; Smith, 2006). The number of inclusive early childhood education institutions is not yet sufficient enough (Nuraeni, 2014), however, these special children need to get an education. Inclusive early childhood education is an educational institution for early age children, which has a license to perform an inclusive education for early age children. Hence, due to the minimum number of inclusive early childhood education institutions which have already had a legal status, as a form of an effort to strengthen early childhood education for all children in Indonesia, then children of an early age with special needs whom have not been accommodated in an inclusive institution are given the opportunity to join a regular early childhood education class. This condition is encouraging and at the same time a challenge for PAUD educators. The educators are happy because the acceptance of children with special needs as students means that an equal of education services for all Indonesian children. On the other hand, the presence of students with special needs in regular classes is a challenge. One of them is an effort to maintain a positive learning climate in the classroom, which involves all students actively in learning activities. Increasing students' understanding and acceptance of their peers who have special needs are one of the important aspects of forming a positive learning atmosphere in the classroom.

The introduction of concepts is important for increasing the sensitivity of early childhood students in an encounter with others with similar characteristics. As a form of knowledge, teachers also strive to develop students' characters, especially social competencies that support the learning process. In the 2013 PAUD Curriculum, the social attitude was a form of Core-2 Competence (KI-2). Social attitude competencies include: being independent, caring, being able to work together, be able to adjust and be able to interact with friends. Furthermore, according to the rules of the Indonesian Minister of Education and Culture number 146/2014 about the 2013 Curriculum for Early Childhood Education, the development target of 5-6 years' children empathy is being able to present a good behavior. It is indicated as the embodied characters of the children. The characteristic of good behavior is expressing with polite, careful, aware of their emotions and others, and also be a friend of others. The efforts of children attitudes and abilities developed in early childhood education based on local and global standards (Kagan, Castillo, Gomez, \& 
Gowani, 2013). The implementation of the standards makes educators and stakeholders easier to monitor children's learning process.

Character education is pivotal, but it should be emphasized that the empathy values developed should be in line with the historical context of the community (Koesoema, 2007). In the efforts to develop empathy, it also needs to consider local wisdom from communities. Safitri, Tirtayani, dan Semara Putra (2018) explain that local wisdom can be included in the stories. Furthermore, it is also explained that educators include various figures for representing certain characters according to the target. The involvement of local values has proven to increase the children's interest in the learning material and process and it also positively evaluated by educators (Hutama, 2016).

Based on this research, PAUD teachers seek to develop one of the foundations of social attitudes, in relation to children with special needs and learning in regular classes, namely empathy. Empathy is the human ability to feel what others are feeling, understand the meaning of the feeling, and then communicate it with such sensitivity to realize a real understanding of the person's feelings (Susanto, 2015). Empathy is the ability to position others and to feel what others are feeling (Carlson \& Wang, 2007; Denham, 2006; Denham \& Brown, 2010; Jones et al., 2016; Papalia, Olds, \& Feldman, 2008). Empathy is a form of social ability that demonstrates the emotions that others sense, and then responds to the purpose of easing the burden, especially on the negative emotions experienced. Related to PAUD character education, the teacher seeks to develop a socially friendly and caring attitude of the students in the classroom.

In the preschool year, which is ages of 4-6 years, children have prominent cognitive ability characteristics, namely the pre-operational ability category and the egocentrism (Denham, 2006; Piaget \& Inhelder, 2010). Based on the characteristics of preschool ages, empathy skills necessary to develop because this capacity will affect the child's ability to accept their's peer and others (Papalia et al., 2008). Children need to know the context of the meaning, at least in their community. Children have to be introduced to the conditions and values that are relevant to empathy and concept of people with special need and also get examples or experiences to behave appropriately. Child early experiences about empathy to special need people have been obtained in their family, and next to the educators have to establish children's another experience regarding empathy behavior in school settings.

An effort to stimulate children ability of empathy conducted through the storytelling methods (Kiing-Bunga \& Kiling, 2016). Using stories in early childhood can be used by visual media such as puppets. The practitioners who are focusing on early childhood development use visual media to facilitate the storytelling session with the goal that the children will have an ability to tell the audience about the puppets' attributes. It also supports the children imagination of the "feeling" which is represented by the puppets. The use of puppets or another three-dimensional medium in the learning process can be acknowledged as an important input for PAUD teachers in conveying the concept of special needs to students. In stimulate efforts of empathy, it is important for teachers to do a repetition of the story in the classroom. When telling stories, the teacher needs to stressing empathy, as a message to students, repeatedly. At the end of the activity, the teachers can ask a question concerning the meaning of a story to the children. It is such as an evaluation for teachers to understand the ability of their students in grasping the values of the stories. In the long-term, teachers can see the changes in student's empathy behavior as an outcome of the learning process.

The selection of the term which is related to the notion of special needs as an idiom of "kurang beruntung" (less fortunate) can attract the threshold of positive emotional reactions of regular students. The less fortunate are corresponding with sadness can be understood as the basis of the human emotional form (Santrock, 2013). In this context, early childhood is located at the learning stage to regulate emotions appropriately and make it happen in the form of behavior and make a new perspective on the situation at hand (Campbell et al., 2016; Halle \& Darling-Churchill, 2016). This learning process is certainly directed at forms of behavior that are accepted socially, namely those that are in accordance with the values and agreements in the social environment. 
When the children recognize their peer group who have special need are experiencing 'less fortunate', they will feel sad about the lack of ability. Concerning this situation, children manage their emotion and response by considering social values. It happens because the children wish for acceptance from their social circumstances. The combination of the two facts causes discomfort to the child. As an individual, the child needs an effort to eliminate the unpleasant. The need to stop this feeling is to trigger the children to take a new perspective to approve and engage with a friend with special needs. The demand is a challenge for teachers to introduce the special need and try to stimulate an appropriate social response to the other children with special needs.

The story is not merely an introduction to myths, but also the facts that are packaged in such a way. Through modification of the content and plot, stories contain moral and humanist values. The values are reference from the local culture. The kind of activity tends to develop a good character for children. It also promotes local culture as valuable resources. The storytelling is not only the packaging of cognitive aspect, however, but it should also develop an effective and psychomotor domain. Stories that have the capacity to reach a child's ability to understand the feeling of characters will make them able to present helpful attitudes and behaviors. This experience will push the children to act to help those poor characters. For example, the children ability in the learning process to engage with an experience of the children with special needs can build positive behavior. This is reflecting the empathy behavior of the children. Teachers assess that empathy ability is the beginning of children's acceptance of various characters of human conditions. The affirmation will lead the children to involve in the classroom activity together with their special need friends.

This research indicates that teachers use the term of "anak kurang beruntung" (the children with less unfortunate) to describe children with special needs. The term is used as a basis that children with special need must accept their condition as taken for granted and it means there is no chance to reject. The abnormalities in the children with this case are a denial condition. Teachers consider that early childhood tends to easy to pay attention to poor people. For example, children easily pay attention to the figure with having a disadvantage situation such as lost their family/friend, objects or others sadness. Through this research, it is important to understand that empathy is a primary foundation to build antibullying generation from an early age.

\section{Conclusion and Suggestion}

Based on the analysis of research data, it can be concluded that the application of the method of storytelling with modifications from local Balinese folktales to early age students in PAUD is effective to increase a positive understanding and social response to children with special needs. A series of preparations for applying the storytelling method need to be considered. First, the teacher determines the goal or target material, then chooses the media used in the form of Balinese folktales (satua) which contains concepts with special needs (types and characteristics). Next, the teacher modifies the contents and storyline as needed, and complements the story with visual aids media. The method of storytelling is effective because there is involvement of motion and song (active storytelling) and is accompanied by the use of visual aids (images).

The teacher attempts to modify the local story by including important elements of the children with special needs' concept and appropriate attitudes and social responses to children who have special needs. Nevertheless, of course, the learning media has not been properly tested. Furthermore, it needs to develop the learning media that accommodate children with special needs and local wisdom. This is important considering that character formation starts from local values and it is similar that PAUD emphasizes contextual learning.

\section{Acknowledgments}

Authors would like to express their gratitude to the Ministry of Research, Technology and High Education for its support through Penelitian Dosen Pemula Tahun 2018, with the research contract No.: 192/UN48.15/LT/2018. The authors also would like to thank Lembaga 
Penelitian dan Pengabdian Masyarakat (LPPM) Universitas Pendidikan Ganesha, research participants, and various organizations and individuals that have helped in the course of conducting this research, whom the authors cannot mention one by one

\section{References}

Basith, A., \& Hengky. (2017). Parents Acceptance to Visual Impaired Children in Special School at Singkawang. Jurnal Pendidikan Indonesia, 6(2), 141-146. https://doi.org/10.23887/jpi-undiksha.v6i2.9342

Campbell, S. B., Denham, S. A., Howarth, G. Z., Jones, S. M., Whittaker, J. V., Williford, A. P., ... Darling-Churchill, K. (2016). Commentary on the review of measures of early childhood social and emotional development: Conceptualization, critique, and recommendations. Journal of Applied Developmental Psychology, 45, 19-41. https://doi.org/10.1016/j.appdev.2016.01.008

Carlie, A. (2013). Permanent exclusion from school and institutional prejudice: Creating change through critical bureaucracy. Rotterdam, Boston \& Taipei: Sense Publishers.

Carlson, S. M., \& Wang, T. S. (2007). Inhibitory control and emotion regulation in preschool children. Cognitive Development, 22(4), 489-510. https://doi.org/10.1016/j.cogdev.2007.08.002

Darling-Churchill, K. E., \& Lippman, L. (2016). Early childhood social and emotional development: Advancing the field of measurement. Journal of Applied Developmental Psychology, 45, 1-7. https://doi.org/10.1016/j.appdev.2016.02.002

Denham, S. A. (2006). Social-Emotional Competence as Support for School Readiness: What Is It and How Do We Assess It? Early Education \& Development, 17(1), 57-89. https://doi.org/10.1207/s15566935eed1701_4

Denham, S. A., \& Brown, C. (2010). "Plays Nice With Others": Social-Emotional Learning and Academic Success. Early Education \& Development, 21(5), 652-680. https://doi.org/10.1080/10409289.2010.497450

Diono, A. (2014). Program Rehabilitasi Sosial Penyandang Disabilitas dan Pergeseran Paradigma Penanganan Penyandang Disabilitas. Buletin Jendela Data Dan Informasi Kesehatan, 2, 19-24.

Guba, E. G., \& Lincoln, Y. S. (1994). Competing Paradigms in Qualitative Research. In N. K. Denzin \& Y. S. Lincoln (Eds.), Handbook of Qualitative Research (pp. 105-117). London, Thousand Oaks, New Delhi, and Singapore: Sage.

Hallahan, D. P., Kauffman, J. M., \& Pullen, P. C. (2015). Exceptional learners: An introduction to Special Education (13th ed.). Upper Saddle River, NJ: Pearson Education Inc.

Halle, T. G., \& Darling-Churchill, K. E. (2016). Review of measures of social and emotional development. Journal of Applied Developmental Psychology, 45, 8-18. https://doi.org/10.1016/j.appdev.2016.02.003

Haryanto. (2010). Diagnosis dan Asesmen: Tumbuh Kembang Anak Berkebutuhan Khusus Usia Dini. Yogyakarta: Venus Gold Press.

Hopman, J. A. B., Tick, N. T., van der Ende, J., Wubbels, T., Verhulst, F. C., Maras, A., ... van Lier, P. A. C. (2018). Special education teachers' relationships with students and self-efficacy moderate associations between classroom-level disruptive behaviors and emotional exhaustion. Teaching and Teacher Education, 75, 21-30. https://doi.org/10.1016/j.tate.2018.06.004

Hutama, F. S. (2016). Pengembangan bahan ajar IPS berbasi budaya Using untuk siswa sekolah dasar. Jurnal Pendidikan Indonesia, 5(2), 113-124.

Jones, S. M., Zaslow, M., Darling-Churchill, K. E., \& Halle, T. G. (2016). Assessing early childhood social and emotional development: Key conceptual and measurement issues. Journal of Applied Developmental Psychology, 45, 42-48. https://doi.org/10.1016/j.appdev.2016.02.008

Kagan, S. L., Castillo, E., Gomez, R. E., \& Gowani, S. (2013). Understanding and Using Early Learning Standards for Young Children Globally. International Journal of Child Care and Education Policy, 7(2), 53-66. https://doi.org/10.1007/2288-6729-7-2-53 
Kementerian Pendidikan dan Kebudayaan. Undang-undang Sistem Pendidikan Nasional, Pub. L. No. 20, 24 (2003). Indonesia: Kementerian Pendidikan dan Kebudayaan Republik Indonesia.

Kementerian Pendidikan dan Kebudayaan. (2016). Statistik Sekolah Luar Biasa (SLB) 2016/2017. Jakarta: Setjen Kemdikbud.

Kiing-Bunga, B. N., \& Kiling, I. Y. (2016). Developing Empathy Ability by Story-Telling with Puppet for Early Childhood Student in Lentera Alam Learning Center. MANASA - Jurnal IImiah Psikologi, 5(2), 114-124.

Kocaj, A., Kuhl, P., Jansen, M., Pant, H. A., \& Stanat, P. (2018). Educational placement and achievement motivation of students with special educational needs. Contemporary Educational Psychology, 55, 63-83. https://doi.org/10.1016/j.cedpsych.2018.09.004

Koesoema, D. (2007). Pendidikan Karakter Strategi Mendidik Anak di Zaman Global. Jakarta: PT. Grasindo.

Kreuger, R. (1988). Focus Groups: a Practical Guide for Applied Research. London: Sage Publications.

Kustawan, D., \& Yani, M. (2013). Mengenal Pendidikan Khusus Serta Implementasi. Jakarta: PT Luxima Metro Media.

Lokadata. (2017). Siswa Penyandang Disabilitas Berdasarkan Provinsi 2017/2018. Retrieved May 19, 2018, from https://lokadata.beritagar.id/chart/preview/siswapenyandang-disabilitas-berdasarkan-provinsi-1520847488

Mastuti, D. (2014). Kesiapan Taman Kanak-kanak dalam Penyelenggaraan Kelas Inklusi Dilihat dari Program Kegiatan Pembelajaran. Belia - Journal of Early Childhood Education Paper, 3(1), 1-8.

Morgan, D. (1988). Focus Groups as Qualitative Research. London: Sage Publications.

Mujaddid. (2014). Kesehatan Anak dengan Disabilitas. Buletin Jendela Data Dan Informasi Kesehatan, 2, 25-30.

Nur'aini, F. (2010). Membentuk Karakter Anak dengan Dongeng. Surakarta: Indi Parent.

Nuraeni. (2014). Pendidikan Inklusif di Lembaga PAUD. Jurnal Kependidikan, 13.

Papalia, D. E., Olds, S. W., \& Feldman, R. D. (2008). Human Development (Psikologi Perkembangan) (9th ed.). Jakarta: Kencana Prenadamedia Group.

Piaget, J., \& Inhelder, B. (2010). Psikologi Anak. Yogyakarta: Pustaka Pelajar.

Rachmawati, M. A., Nu'man, T. M., Widiasmara, N., \& Wibisono, S. (2016). Differentiated Instruction for Special Needs in Inclusive Schools: A Preliminary Study. Procedia Social and Behavioral Sciences, 217, 585-593. https://doi.org/10.1016/j.sbspro.2016.02.053

Ruijs, N. (2017). The impact of special needs students on classmate performance. Economics of Education Review, 58, 15-31. https://doi.org/10.1016/j.econedurev.2017.03.002

Rutherford, G. (2016). Questioning special needs-ism: Supporting student teachers in troubling and transforming understandings of human worth. Teaching and Teacher Education, 56, 127-137. https://doi.org/10.1016/j.tate.2016.02.009

Safitri, N. K. D. A., Tirtayani, L. A., \& Semara Putra, D. B. K. N. (2018). Pengaruh Cerita Pendek Berbasis Kearifan Lokal terhadap Kemampuan Empati Anak Kelompok B PAUD Gugus Anggrek. Jurnal Pendidikan Anak Usia Dini Undiksha, 6(1).

Santrock, J. W. (2013). Life-span Development 14th ed. New York: McGraw-Hill Companies, Inc. (14th ed.). New York: McGraw-Hill.

Smith, D. (2006). Inklusi, Sekolah yang Ramah untuk Semua. Bandung: Penerbit Nuansa.

Supatra, I. N. K. (2016). Satua Bali I Belog. Denpasar: CV Kayumas Agung.

Susanto, A. (2015). Bimbingan dan Konseling di Taman Kanak-kanak. Jakarta: Prenada Media Group.

Taro, M. (2014). Dongeng-dongeng Karmaphala. Denpasar: Amada Press.

Tim Dirjen Pembinaan Kesmas. (1997). Pedoman Deteksi Dini Tumbuh Kembang Balita. Jakarta: Departemen Kesehatan Republik Indonesia.

Tinggen, I. N. (1994). Satua-satu Bali (10th ed.). Singaraja: Indra Jaya. 